\title{
I 0 I 2 Cardiac surgery results in anterior translocation of the left ventricle in systole and tethering of the right ventricular free wall - an explanation for post-operative paradoxical septal motion Subodh B Joshi*, Ali K Salah, Dorinna D Mendoza, Joseph Lindsay Jr, Steven A Goldstein and Anthon R Fuisz
}

Address: Washington Hospital Center, Washington, DC, USA

* Corresponding author

from I th Annual SCMR Scientific Sessions

Los Angeles, CA, USA. I-3 February 2008

Published: 22 October 2008

Journal of Cardiovascular Magnetic Resonance 2008, IO(Suppl I):AI37 doi:I0.II86/I532-429X-I0-SI-AI37

This abstract is available from: http://jcmr-online.com/content/I0/SI/AI37

(c) 2008 Joshi et al; licensee BioMed Central Ltd.

\section{Introduction}

Abnormal (paradoxical) interventricular septal motion is commonly noted on echocardiography after cardiac surgery. Its mechanism has been debated. Cardiac magnetic resonance imaging (MRI) allows for accurate assessment of movement of the heart relative to the chest wall.

\section{Purpose}

To compare the motion of cardiac structures pre and post cardiac surgery.

\section{Methods}

Patients scheduled for coronary artery bypass surgery were prospectively enrolled to undergo cardiac MRI before and three months after surgery. On a mid left ventricular (LV) short axis cine image the positions of myocardial landmarks were ascertained relative to a stationary anterior reference point. Systolic wall thickening (SWT) in the mid septum was assessed on the same images. Viability images and echocardiography results were also reviewed.

\section{Results}

23 patients were identified, 19 male, mean age 64 years. Table 1 describes the motion of the structures indicated. A negative sign indicates posterior motion in systole and a positive sign an anterior movement. Scar in the inter-ventricular septum was identified in three patients. Paradoxical septal motion was noted in 7 of the 8 patients in whom post-operative echocardiograms were available.

\section{Conclusion}

After cardiac surgery the entire left ventricle moves anteriorly in systole. There is reduced motion of the right ventricular free wall suggestive of tethering to chest wall. This pattern of movement post-operatively occurs despite preserved septal wall thickening and improved global left and right ventricular function. 
Table I:

\begin{tabular}{llll}
\hline \multicolumn{4}{c}{ Motion in Systole, + Anterior, - Posterior } \\
\hline & Pre CABG & Post CABG & P value \\
\hline RV wall (mm) & -5.2 & -2.3 & 0.002 \\
Septum (mm) & -1.5 & 3.7 & $<0.001$ \\
Mid LV cavity (mm) & -0.9 & 6.7 & $<0.001$ \\
Lateral LV wall (mm) & 3.5 & 8.6 & $<0.001$ \\
Septal SWT (\%) & $54 \%$ & $49 \%$ & 0.56 \\
LVEF (\%) & $50 \%$ & $60 \%$ & $<0.001$ \\
RVEF (\%) & $52 \%$ & $60 \%$ & $<0.001$ \\
\hline
\end{tabular}

Publish with Bio Med Central and every scientist can read your work free of charge

"BioMed Central will be the most significant development for disseminating the results of biomedical research in our lifetime. " Sir Paul Nurse, Cancer Research UK

Your research papers will be:

- available free of charge to the entire biomedical community

- peer reviewed and published immediately upon acceptance

- cited in PubMed and archived on PubMed Central

- yours - you keep the copyright

Submit your manuscript here:

http://www.biomedcentral.com/info/publishing_adv.asp 